\title{
Comparative Efficiency of Table Egg Farms Under Two Different Production Systems in Oyo State, Nigeria
}

\author{
Adedeji Adeyinka Paul, ${ }^{1, *}$, Okuneye Peter Adebola ${ }^{1}$, Akerele Dare $^{1}$, Isah Olubukola ${ }^{2}$ \\ ${ }^{1}$ Department of Agricultural Economics and Farm Management, Federal University of Agriculture, Abeokuta, Ogun State, Nigeria \\ ${ }^{2}$ Department of Animal Nutrition, Federal University of Agriculture, Abeokuta, Ogun State, Nigeria \\ *Corresponding author: adedejiadeyinka3584@gmail.com
}

\begin{abstract}
This study was a comparative economic analysis of poultry egg production under different production systems in Oyo State, Nigeria. Primary data were collected with the aid of a structured questionnaire from 134 (75 battery cage and 59 deep litter systems) poultry farmers through a multistage sampling procedure in three agricultural zones of the State. Descriptive statistics, budgetary techniques, Data Envelopment Analysis (DEA), Tobit regression and student-t test methods were used to analyze the data. Results showed that the mean ages of the farmers were 44 and 40years for battery cage and deep litter systems respectively, while $97.3 \%$ and $97.0 \%$ of battery cage and deep litter system users had formal education respectively. Also, $78.9 \%$ and $88.1 \% ; 65.3 \%$ and $57.6 \%$; $25.3 \%$ and $28.8 \%$ of battery cage and deep litter users were male, members of cooperative society and had extension contacts respectively while $57.3 \%$ and $76.3 \%$; 86.7 and $84.8 \%$ of battery cage and deep litter users used Isah Brown breed and commercial feed respectively. The Net Farm Incomes (NFI) per bird for battery cage system were $\$ 2,052.17$; $\$ 1,282.86$ and $\$ 1,605.28$ while that of deep litter system were $\$ 1,897.84 ; \$ 1,467.46$ and $\$ 1,236.06$ for small, medium and large scale farmers respectively. DEA revealed that the mean technical efficiencies for battery cage and deep litter systems were 0.892 and 0.912 . Tobit regression revealed that the determinants of technical efficiency of farmers using battery cage system were extension visits $(p<0.01)$; gender $(p<0.01)$; farmers' years of education $(p<0.05)$ and membership of cooperative society $(p<0.05)$. Also, the efficiency of farmers using deep litter system was influenced by breed of bird $(p<0.01)$; feed type $(p<0.01)$ and gender $(p<0.01)$. This study concluded that there is no efficiency loss in the choice of either of the systems, except that expansion may be restricted in deep liter system if land constraints exist. The study recommended that farmers who wish to invest in poultry egg production are at liberty to choose either of the systems depending on the intended scale of production.
\end{abstract}

Keywords: comparative, efficiency, determinants, table egg farms, deep litter, battery cage, data envelopment analysis, Oyo state, Nigeria

Cite This Article: Adedeji Adeyinka Paul, Okuneye Peter Adebola, Akerele Dare, and Isah Olubukola, "Comparative Efficiency of Table Egg Farms Under Two Different Production Systems in Oyo State, Nigeria." World Journal of Agricultural Research, vol. 5, no. 3 (2017): 135-146. doi: 10.12691/wjar-5-3-3.

\section{Introduction}

Despite the numerous economic importance of agriculture, the sector is presently in distress and Nigeria which was once a food exporter is now a food importing nation [1]. The livestock sub-sector is equally very important to the national economy as it serves as the major supplier of the highly essential animal protein. The importance of livestock sub-sector is in line with recommendation of the Food and Agricultural Organization [2] that on the average, a man's daily protein intake should be between $65-72$ grams and 53\% (about 35 grams) of this should be animal based.

According to the Food and Agricultural Organization, the major Nigerian Livestock resources consist of about 15,149,000 cattle, 49,000,000 sheep and goats, 6,112,000 pigs and $131,125,000$ poultry [3]. From these figures, poultry represents about 65.11 percent of the total livestock resources, which indicates the place of pride that the poultry sub sector enjoys in the livestock industry. The poultry industry has many branches; the two main branches are egg and table meat production. The other branches include the production of chicks; point of lay pullets or ready to lay birds and of poultry feed; the manufacturing of poultry equipment, as well as the processing or marketing of eggs and table birds [4].

The federal government in bid to encourage the poultry industry in Nigeria, in 2002 banned the importation of poultry and products, therefore one way of bridging demand and supply in the diets of average Nigerian is through the intensive rearing of poultry and other domestic avians. Nigeria, like many other developing countries is facing the problems of shortage of dietary animal protein. The gravity of this problem is becoming more intense with the growing population and urbanization [5]. In Nigeria, the daily animal protein intake is below the recommended minimum level of $65 \mathrm{gm}$ per caput per day. It is observed that only $8.4 \mathrm{gm}$ of the $53.8 \mathrm{gm}$ of protein consumption level of Nigerians is derived from animal sources, less than $16 \%$ contribution 
of animal products to protein consumption of Nigerians, this is very poor indeed when compared with countries like USA with about $69 \%$ of the total protein derived from animal sources [6]. Due to this acute shortage of animal protein in the diet of an average Nigerian, there is the need to increase the production of domestic animals, which are conventional sources of animal protein.

Egg, which is one of the major products of poultry production, is one of the most nutritious and complete foods known to man. Chicken egg protein has biological value of 1.0 and so shares with human protein the distinction of being a perfect protein. Egg is more easily affordable by the common man than other sources of animal protein.

Poultry has some unique advantages such as high profligacy, fast growth rate and efficient feed utilization and conversion over all other animals, which make them good species of animals to multiply extensively to combat protein shortages. Furthermore, easy access to poultry products by various classes of Nigerians given their wide production makes it appropriate to increase its production, hence its availability.

Commercial poultry is well established in the country with substantial infrastructure (poultry houses, feed mills, hatcheries and processing plants) already on ground. However, most of these items became idle for reasons associated with high cost of strategic inputs and working capital as well as competition from cheap imports. The embargo placed on the importation of poultry products in 2002 which has also been reviewed many times over by successive administrations to include outright ban, increased tariff and duties by the Federal Government is aimed at encouraging local production. The challenge therefore, is how to produce poultry products at substantial levels in order to bridge the protein demandsupply gap in the nearest future [7].

Research has found out that high temperature is detrimental to efficient production and reproduction by poultry [8]. The research reported that under elevated temperatures, feed intake and egg production are reduced $[9,10]$. In tropical climate, one way to alleviate heat stress on poultry is by improving their habitat. Poultry farmers in developing countries have housed their poultry in open floor pen (deep litter) than in battery cages [11]. The issue then is, are these the sources of inefficiency in poultry production and which system is most affected?

It is a common practice among poultry egg farmers in Nigeria to adopt either battery cage or deep litter housing system for egg production depending on availability of capital as well as other resources. Optimum production efficiency can be achieved by effective utilization of the available inputs thus improving the levels of outputs. The efficiency with which farmers use available resources and improved technology is important in agricultural production [12]. Increased efficiency associated with the quality of resources used and the right choice of better technology, reduce wastage and increase production. Wrong choices on the types of inputs and technologies to adopt in poultry production in a particular location and at a particular time results in poor efficiency and eventually poor output. In order to achieve optimum production level, resources must be available and in whatever quantity resources must be efficiently utilized to maximize output [13].

Some of the problems of poultry production in Nigeria include low productivity and inefficiency in resource allocation and utilization [14]. Therefore one way to realize sustainability in the table egg business is to look for ways to improve on the efficiency of the farms that make up the poultry sub sector. Several works have been carried out on the technical efficiency of poultry egg farms which failed to show the relative efficiencies of the farms based on the type of system that is being employed on the farm. There is therefore a need to further compare the efficiencies of poultry egg farms based on the type of systems employed viz battery cage and deep litter in order to look at ways at which higher outputs and productivity can be achieved to raise the efficiencies can be achieved with or without increasing the resource base and in the process lead to sustained productivity.

This study is therefore focused on the profitability and determinants of technical efficiency of table egg farms under battery cage and deep litter farms in Oyo state, Nigeria. As a result, this study raised the following specific objectives:

i. Describe and compare the socio economic characteristics of battery cage and deep litter poultry egg farmers in the study area.

ii. Identify and compare the costs and returns associated with poultry egg farms under battery cage and deep litter production systems and establish which of the production systems is more profitable.

iii. Estimate the technical efficiency of poultry egg farms under the two production systems.

iv. Identify the determinants of technical efficiency of poultry egg farms under the two production systems.

This study will help farmers make better choice when it comes to the type of production systems they are to adopt in the production of table eggs. This study will help farmers make better choice when it comes to the type of production systems they are to adopt in the production of table eggs.

\section{Methodology}

This study was carried out in Oyo State, Nigeria. Out of the 36 states in Nigeria, Oyo state has the second highest number of poultry holders in the country with approximately 407,547 chicken holders following Kogi state which has the highest number with 502,716 chicken holders in the country. Oyo state is also one of the highest producers of egg among the 36 states in Nigeria [15], furthermore, the two production systems are economically practiced.

Primary data were collected with the aid of a structured questionnaire from egg farms which include information about the farms namely: (age of the farm, location, number of birds, number of workers etc.) and costs and returns to production (fixed and variable costs, number of eggs sold, etc.). Multi-stage sampling technique was used in selecting the respondents from the study area. A total of 134 poultry farmers were reached with the aim of getting 
the needed information as regards the study as it relates to them. The first stage was a random selection of three (3) zones from the four (4) agricultural zones in the state; the second stage was a random selection of two (2) local government areas from each of the three zones while the last stage involved a snowball selection of seventy five (75) farms using battery cage system and fifty nine (59) farms using deep litter system giving a total of one hundred and thirty four (134) respondents.

The data obtained from the farms were analyzed using the various methods of data analysis including Descriptive Statistics, Budgetary Technique, Data Envelopment Analysis and Tobit Regression. Descriptive statistics such as means, percentages, and frequency distribution tables were used to describe the socio economic characteristics of the respondents. Descriptive statistics and budgetary statistics such as means, percentages and frequency distribution tables were used to describe and compare the various costs and returns to poultry egg farming in the study area while budgetary analysis was used to examine which of the poultry egg production systems in the study area is more profitable. Budgetary analysis enables the estimation of the total costs as well as returns within a production period. The mathematical notation for calculating the gross margin is shown in the equation below:

$$
\mathrm{GM}=\mathrm{p}_{\mathrm{i}} \mathrm{y}_{\mathrm{i}}-\mathrm{r}_{\mathrm{i}} \mathrm{c}_{\mathrm{i}}
$$

$\mathrm{GM}=$ Total Revenue $(\mathrm{TR})-$ Total Variable Cost $(\mathrm{TVC})$

$$
\begin{array}{ll}
\text { Where: } & \text { GM = Gross margin (Naira) } \\
p_{i} y_{i} & =\text { Total revenue (Naira) } \\
r_{i} c_{i} & =\text { Total variable cost (Naira) } \\
p_{i} & =\text { Price of table eggs per tray (Naira) } \\
y_{i} & =\text { Quantity of eggs sold (Trays) } \\
\mathrm{r}_{\mathrm{i}} & =\text { Unit price of each variable input used (Naira) } \\
\mathrm{c}_{\mathrm{i}} & =\text { Quantity of each variable input used }
\end{array}
$$

Total variable cost (TVC):

$$
\mathrm{TVC}=\mathrm{X}_{1}+\mathrm{X}_{2}+\mathrm{X}_{3}+\mathrm{X}_{4}+\mathrm{X}_{5}+\mathrm{X}_{6}
$$

$$
\begin{aligned}
& \mathrm{X}_{1}=\text { Bird Cost (Naira) } \\
& \mathrm{X}_{2}=\text { Labour Cost (Naira) } \\
& \mathrm{X}_{3}=\text { Feed Cost (Naira) } \\
& \mathrm{X}_{4}=\text { Medication Cost (Naira) } \\
& \mathrm{X}_{5}=\text { Energy Cost (Naira) } \\
& \mathrm{X}_{6}=\text { other variable costs (Naira) } \\
& \qquad \mathrm{GM}=\mathrm{TR}-\mathrm{TVC} \\
& \mathrm{NFI}=\mathrm{GM}-\mathrm{TFC} .
\end{aligned}
$$

The Rate of Returns on Investment (RROI) and Rate of Returns on Fixed Cost (RRFC) were used to determine and compare the measure of financial outcome of the poultry egg farmers that uses either battery cage or deep litter system in the study area. They were calculated using the formula below:

$$
\begin{aligned}
& \text { RROI }=\frac{\text { Net Farm Income }}{\text { Total Cost }} \mathbf{x 1 0 0} \\
& \mathbf{R R F C}=\frac{\text { Gross Margin }}{\text { Total Fixed Cost }} \mathbf{1 1 0 0 .} .
\end{aligned}
$$

The straight line depreciation method was used to calculate the depreciation cost of the equipment (fixed asset) used in poultry egg production for both battery cage users and deep litter users in the study area.

$$
\text { Annual Depreciation }=\frac{P p-S}{n} .
$$

Where;

$\mathrm{Pp}=$ Purchase price

$\mathrm{S}=$ Salvage value

$\mathrm{n}=$ No of years of the useful life of the asset.

The difference of mean analysis was done to test the significant difference between the profit levels of poultry egg farmers that use battery cage and poultry egg farmers that use deep litter system under small, medium and large scale production in the study area. The total sample size that was considered for both battery cage and deep litter system in the study was one hundred and thirty four (134).

$$
\mathbf{T}=\frac{\overline{\mathbf{X}_{1}}-\overline{\mathbf{X}_{2}}}{\sqrt{\frac{\sigma_{1}^{2}}{\mathbf{n}_{1}}+\frac{\sigma_{2}^{2}}{\mathbf{n}_{2}}}}
$$

Where:

$\overline{X_{1}}=$ Mean Net Farm Income of farmers that use battery cage system

$\overline{X_{2}}=$ Mean Net Farm Income of farmers that use deep litter system

$\sigma_{1}=$ Variance of Net Farm Income of farmers that use battery cage system

$\sigma_{2}=$ Variance of Net Farm Income of farmers that use deep litter system

$\mathrm{n}_{1}=$ Number of farmers that use battery cage system

$\mathrm{n}_{2}=$ Number of farmers that use deep litter system

The Rule of thumb is to reject the null hypothesis i.e $\mathrm{H}_{\mathrm{o}}$ if Tcal is greater than Ttab and fail to reject if otherwise.

Data Envelopment Analysis was used to estimate the technical efficiency of the poultry egg farmers under the two production systems in the study area.

Data Envelopment Analysis used is highlighted thus:

The non-parametric approach DEA, known as Data Envelopment Analysis with input orientation of the model and variable returns to scale (VRS) was used to quantify the technical efficiency. Technical efficiency of the individual production unit measured as efficiency score was expressed in relation to this unit as the relative parameter (non- dimensional number). It numerically expresses the distance of the given production unit to the efficiency limit. It is assumed that all production units are lying either on the efficiency limit or under it.

Formal notation of DEA used which will follow a linear programming method is as follows:

$$
\begin{aligned}
& \max \Phi, \lambda \Phi \\
& \text { subject to } \\
& -\Phi y_{\mathrm{i}}+\mathrm{Y} \lambda \geq 0 \\
& \mathrm{x}_{\mathrm{i}}-\mathrm{X} \lambda \geq 0 \\
& \lambda \geq 0
\end{aligned}
$$

where $\varphi$ is a scalar, $\lambda$ is a Nx1 vector of weights, $X$ is a $\mathrm{NxK}$ matrix of input quantities for all $\mathrm{N}$ farms, $\mathrm{Y}$ is a $\mathrm{NxM}$ matrix of output quantities for all $\mathrm{N}$ farms, $\mathrm{xi}$ is a 
$\mathrm{Kx} 1$ vector of input quantities for the ith farm and $\mathrm{y}_{\mathrm{i}}$ is a Mx1 vector of output quantities for the ith farm.

The input oriented variable return to scale used to determine how much of the input mix the farmers would have to change to achieve the output level that coincides with the best practice frontier.

The data envelopment analysis relative measurement of efficiency where the general problem is given as:

$$
\operatorname{MaxTE}=\frac{\sum_{r=1}^{s} \alpha_{r} Y_{r o}}{\sum_{r=1}^{m} \beta_{i} V_{i o}}=\frac{q}{q^{*}} .
$$

Subject to:

$$
\frac{\sum_{r=1}^{s} \alpha_{r} Y_{r j}}{\sum_{r=1}^{m} \beta_{i} V_{i j}} \leq 1, \ldots, n
$$

Where:

$V_{i j}=$ Quantities of the $i^{\text {th }}$ input of the $j^{\text {th }}$ farm

$Y_{r j}=$ Quantities of the $r^{\text {th }}$ output of the $j^{\text {th }}$ farm.

The variables of the Data Envelopment Analysis model are further disaggregated below

$\mathrm{Y}_{1}=$ Amount of eggs produced (trays)

$\mathrm{Y}_{2}=$ No of culled layers sold during the period

$\mathrm{V}_{1}=$ Number of birds

$\mathrm{V}_{2}=$ Quantity of Labour used (hrs)

$\mathrm{V}_{3}=$ Quantity of feed used $(\mathrm{Kg})$

$\mathrm{V}_{4}=$ Quantity of water consumed (Litres)

$\mathrm{V}_{5}=$ Number of Medication visits.

Tobit regression was used to identify the determinants of technical efficiency of the poultry farmers. Since the technical efficiency scores of each farm ranged from 0 to 1, Tobit regression becomes appropriate with the dependent variable censored at 1 regressed against a number of independent variables. The regression function is given below:

$$
\mathrm{TE}_{\mathrm{i}}=\beta_{0}+\mathrm{B}_{\mathrm{i}} \mathrm{W}_{\mathrm{ji}}+\mu_{\mathrm{i}}
$$

where: $\mathrm{TE}_{\mathrm{i}}=$ Technical efficiency of the ith farm

$\beta_{0}=$ Intercept of the regression equation

$\beta_{\mathrm{i}}=$ Regression coefficients of the individual independent variables $\mathrm{i}$

$\mathrm{W}_{\mathrm{ji}}=$ Independent variables

$\mu_{\mathrm{i}}=$ error term.

The explanatory variables to be included in the Tobit regression model are:

$\mathrm{W}_{1}=$ age of the farm manager/proprietor

$\mathrm{W}_{2}=$ age of the farm

$\mathrm{W}_{3}=$ Years of experience of the farm manager/proprietor

$\mathrm{W}_{4}=$ Years of education of the farm manager/proprietor

$\mathrm{W}_{5}=$ breed of the bird (dummy variable Isah Brown $=$

1,0 otherwise)

$\mathrm{W}_{6}=$ Number of breakages

$\mathrm{W}_{7}=$ Membership of cooperative societies (dummy variable $\mathrm{Yes}=1, \mathrm{No}=0$ )

$\mathrm{W}_{8}=$ Registration with Poultry Association of Nigeria

(dummy Yes $=1$, No $=0$ )

$\mathrm{W}_{9}=$ Extension Visits (Numbers)

$\mathrm{W}_{10}=$ Type of feed used (dummy variable Commercial

$=1$, Self-formulated $=0$ )

$\mathrm{W}_{11}=$ Gender of the manager (dummy variable Male $=1$, Female $=0$ )
$\mathrm{W}_{12}=$ Marital Status (dummy variable Married $=1,0$ otherwise)

$\mathrm{W}_{13}=$ Scale of operation (dummy variable Medium and large scale $=1$, small scale $=0$ )

\section{Results and Discussions}

Table 1 shows the distribution of the respondents according to the gender, age, marital status, religion and level of education; it reveals that $78.7 \%$ of the farmers are male and $21.3 \%$ of them are female for farms using battery cage system while for those using deep litter system, $88.1 \%$ of them are male while $11.9 \%$ are female. The participation of more males than females in poultry business may be due the stress involved in poultry egg production which may deter most females from wanting to invest in the venture. Also, the involvement of less female compared to male in egg production could be due to the assumption that females are less efficient than male poultry egg farmers [16]. The mean age of the farmers using battery cage system is 44years with majority (about $72 \%$ ) of them below 51years old; majority ( $83.1 \%)$ of the farmers using deep litter system also less than 51years old with a mean age of $40 y e a r s$, the mean age of 42 years for all the poultry farmers shows that majority of the farmers are still in their active years therefore the stress and rigors of poultry egg production does not seem to be an hindrance to their involvement in poultry production because of their agility and strength. The table also reveals that majority $(82.7 \%)$ of the farmers using battery cage and $79.7 \%$ of those using deep litter system are married. That majority of the poultry farmers are married is an indication of the availability of family labour for the enterprise.

Majority (about 76\%) of the farmers using battery cage system are educated beyond the secondary school level; also about $73.3 \%$ of them which represents a big majority have above 5years experience in poultry egg production with the mean years of experience in poultry egg production at 11years. For the farmers making use of the deep litter system, $74.4 \%$ and $73.9 \%$ which is a majority have education beyond secondary school and years of experience greater than five years respectively with 11 years as the average years of experience. The high level of education and high years of experience is expected to positively influence the productivity as well as the efficiency of the farms due to some of the managerial as well as technical decisions that may be required at some point in the production process.

The distribution of poultry farmers according to formal training in egg production, registration with the Poultry Association of Nigeria (PAN), age of the farm and number of birds is presented in Table 2. The study revealed that $62.7 \%$ and $30.5 \%$ of the farmers using battery cage and deep litter systems respectively had no formal training in egg production before venturing into the enterprise while $37.3 \%$ and $69.5 \%$ had formal training in egg production. Majority $(65.3 \%$ and $57.6 \%$ for farms using battery cage and deep litter systems respectively) of the farmers are registered with and are members of the Poultry Association of Nigeria (PAN). The registration with PAN is expected to be beneficial to the farmers as the 
association would afford them the opportunity of having access to new technologies when such are to be introduced and it would also motivate the farmers to produce quality table eggs through the use of quality inputs in order to stave off competition. The mean age of the farms is 10years, for farms using battery cage, with majority $(66.7 \%)$ of them in existence for less than 11years while the average age of the farms using deep litter system is 9years with majority $(72.9 \%)$ of them also in existence for less than 11years. The relatively long years of existence of these farms indicates that the farms are not new in the business of poultry egg production therefore they are expected to be efficient as a result of the wealth of knowledge and mastery of the production of table eggs that they have been able to gather over time. The average no of birds of the farms sampled in the study area is 2,172 birds for the whole population of both systems while it is 2,868 and 1,289 birds for battery cage and deep litter systems respectively.
Depending on the number of birds owned by the proprietors of each farm, the poultry farms are divided into various scales of operation. According to $[17,18,19]$, poultry egg farmers having less than 1001 birds were considered as small scale farmers, 1001-3000 as medium scale farmers while those having above 3000 birds were large scale farmers. The distribution shows that $46.7 \%$ of the farms using battery cage system and $66.1 \%$ of those using the deep litter system are small scale farmers, $30.4 \%$ of those using battery cage system as well as $25.5 \%$ of those using the deep litter system can be classified as medium scale farmers while $24.1 \%$ and $17.2 \%$ of the battery cage and deep litter system farms respectively are deemed as large scale farmers. The relatively higher proportion of farms using deep litter system being small scale farmers as compared to those using battery cage system may be due to the relatively bigger space involved in the deep litter system as well as the stress involved in the daily routines such as egg collection in the system.

Table 1. Distribution of the poultry egg farmers according to their gender, age, marital status, religion, level of education and years of experience

\begin{tabular}{|c|c|c|c|c|c|c|}
\hline \multirow[b]{2}{*}{ Variable } & \multicolumn{2}{|c|}{ Battery Cage } & \multicolumn{2}{|c|}{ Deep Litter } & \multicolumn{2}{|c|}{ Aggregate } \\
\hline & Frequency & $\%$ & Frequency & $\%$ & Frequency & $\%$ \\
\hline \multicolumn{7}{|l|}{ Gender } \\
\hline Female & 16 & 21.3 & 7 & 11.9 & 23 & 17.2 \\
\hline \multicolumn{7}{|l|}{ Age } \\
\hline $21-30$ & 8 & 10.7 & 10 & 16.9 & 18 & 13.4 \\
\hline $31-40$ & 22 & 29.3 & 23 & 39 & 45 & 33.6 \\
\hline $41-50$ & 24 & 32.2 & 15 & 25.5 & 39 & 29.1 \\
\hline$>50$ & 21 & 28 & 10 & 16.9 & 31 & 23.1 \\
\hline Mean & & 44 & & 40 & & 42 \\
\hline \multicolumn{7}{|l|}{ Marital Status } \\
\hline Married & 62 & 82.7 & 47 & 79.7 & 109 & 81.3 \\
\hline Widowed & 2 & 2.7 & 1 & 1.7 & 3 & 2.2 \\
\hline \multicolumn{7}{|l|}{ Religion } \\
\hline Christianity & 60 & 80 & 41 & 69.5 & 101 & 75.4 \\
\hline Islam & 15 & 20 & 18 & 30.5 & 33 & 24.6 \\
\hline \multicolumn{7}{|l|}{ Level of Education } \\
\hline No Formal Education & 2 & 2.7 & 1 & 1.7 & 4 & 3 \\
\hline Primary & 1 & 1.3 & 4 & 6.8 & 4 & 3 \\
\hline Secondary & 10 & 13.3 & 8 & 13.6 & 18 & 13.4 \\
\hline $\mathrm{OND} / \mathrm{NCE}$ & 22 & 29.3 & 16 & 27.1 & 38 & 28.4 \\
\hline $\mathrm{BSC} / \mathrm{HND}$ & 35 & 46.7 & 27 & 45.8 & 62 & 46.3 \\
\hline \multicolumn{7}{|l|}{ Years of Experience } \\
\hline 0 to 5 & 20 & 26.7 & 11 & 18.6 & 35 & 26.1 \\
\hline 6 to 10 & 28 & 37.3 & 17 & 37.3 & 46 & 34.3 \\
\hline 11 to 15 & 13 & 17.3 & 11 & 18.6 & 24 & 28 \\
\hline 16 to 20 & 7 & 9.4 & 8 & 13.5 & 15 & 11.2 \\
\hline 21 to 25 & 3 & 4 & 4 & 6.8 & 7 & 5.2 \\
\hline$>25$ & 4 & 5.3 & 3 & 5.1 & 7 & 5.2 \\
\hline Mean & & 11 & & 11 & & 11 \\
\hline Total & 75 & 100 & 59 & 100 & 134 & 100 \\
\hline
\end{tabular}

Source: Field Survey, 2015. 
Table 2. Distribution of the respondents according to formal training in egg production, registration with PAN, age of the farm and number of birds

\begin{tabular}{|c|c|c|c|c|c|c|}
\hline \multirow[b]{2}{*}{ Variable } & \multicolumn{2}{|c|}{ Battery Cage } & \multicolumn{2}{|c|}{ Deep Litter } & \multicolumn{2}{|c|}{ Aggregate } \\
\hline & Frequency & $\%$ & Frequency & $\%$ & Frequency & $\%$ \\
\hline \multicolumn{7}{|c|}{ Formal Training in Egg Production } \\
\hline Yes & 28 & 37.3 & 18 & 69.5 & 46 & 34.3 \\
\hline No & 47 & 62.7 & 41 & 30.5 & 88 & 65.7 \\
\hline Yes & 48 & 64 & 33 & 55.9 & 81 & 60.4 \\
\hline No & 27 & 36 & 26 & 44.1 & 53 & 39.6 \\
\hline \multicolumn{7}{|c|}{ Membership of Cooperative Society } \\
\hline Yes & 49 & 65.3 & 34 & 57.6 & 83 & 61.9 \\
\hline \multicolumn{7}{|c|}{ Age of Farm } \\
\hline $0-5$ & 28 & 37.3 & 19 & 32.2 & 47 & 35.1 \\
\hline 6 to 10 & 22 & 29.4 & 24 & 40.7 & 46 & 34.3 \\
\hline 11 to 15 & 11 & 14.6 & 8 & 13.5 & 19 & 14.2 \\
\hline $16-20$ & 8 & 10.7 & 5 & 8.5 & 13 & 9.7 \\
\hline$>20$ & 6 & 8 & 3 & 5.1 & 9 & 6.7 \\
\hline Mean & & 10 & & 9 & & 10 \\
\hline \multicolumn{7}{|l|}{ No of Birds } \\
\hline $0-500$ & 16 & 21.3 & 20 & 33.9 & 36 & 26.9 \\
\hline $501-1000$ & 19 & 25.3 & 19 & 32.2 & 38 & 28.3 \\
\hline $1501-2000$ & 7 & 9.7 & 2 & 3.4 & 9 & 6.7 \\
\hline $2001-2500$ & 1 & 1.3 & 2 & 3.4 & 3 & 2.3 \\
\hline $2501-3000$ & 2 & 2.7 & 2 & 3.4 & 4 & 2.9 \\
\hline$>3000$ & 18 & 24 & 5 & 8.5 & 23 & 17.2 \\
\hline Mean & & 2868 & & 1289 & & 2172 \\
\hline Total & 75 & 100 & 59 & 100 & 134 & 100 \\
\hline
\end{tabular}

Source: Field Survey, 2015.

Table 3. Distribution of the respondents according to Access to Extension Agents, Breed of Bird and Type of Feed Used

\begin{tabular}{|c|c|c|c|c|c|c|}
\hline \multirow[b]{2}{*}{ Variable } & \multicolumn{2}{|c|}{ Battery Cage } & \multicolumn{2}{|c|}{ Deep Litter } & \multicolumn{2}{|c|}{ Aggregate } \\
\hline & Frequency & $\%$ & Frequency & $\%$ & Frequency & $\%$ \\
\hline \multicolumn{7}{|c|}{ Extension Visit } \\
\hline No & 56 & 74.67 & 42 & 71.19 & 98 & 73.13 \\
\hline Isah Brown & 43 & 57.33 & 45 & 76.27 & 88 & 65.67 \\
\hline Others & 32 & 42.67 & 14 & 23.73 & 46 & 34.33 \\
\hline \multicolumn{7}{|c|}{ Type of Feed Used } \\
\hline Commercial & 65 & 86.67 & 50 & 84.75 & 115 & 85.82 \\
\hline Self-Prepared & 9 & 12.00 & 8 & 13.56 & 17 & 12.69 \\
\hline Both & 1 & 1.33 & 1 & 1.69 & 2 & 1.49 \\
\hline Total & 75 & 100 & 59 & 100 & 134 & 100 \\
\hline
\end{tabular}

Source: Field Survey, 2015. 
Extension agents' visit to poultry farms is expected to help poultry farms improve on their production through ready access to information on production technology as well as new trends in the industry. The study reveals that about a quarter $(25.33 \%)$ and $28.81 \%$ of the battery cage and deep litter farms respectively had access to extension agents during the last production year. Majority (74.67 for battery cage and 71.19 for deep litter system) of the farmers had no access to extension agents. This therefore imply that extension agents still have a lot of ground to cover in order to reach the poultry egg farmers and all attention shouldn't be directed towards crop farming by extension agencies. This result is also in line with the findings of [20] and [21] who reported that majority of poultry farmers in their study area had no access to extension agents in the production year.

Breed of the bird would influence the production ability and profligacy of the bird hereby impacting on the efficiency of the farmers. The production ability and profligacy of the bird would influence that farmers' decision on which of the breed of bird to employ in order to have optimum production. The result of the study revealed that $57.33 \%$ of the farmers that employ the battery cage system made use of Isah Brown breed while the remaining $42.67 \%$ used other breeds like Abhor Acre. For farmers that use the deep litter system, 76.27\% of them made use of Isah Brown breed.

The decision to employ the use of either commercial feed or self-prepared feed will be predicated on a number of factors such as cost of the feed, presence of the requisite feed composition and availability. The study revealed that $86.67 \%$ and $84.75 \%$ of the farmers that use battery cage system and deep litter system respectively made use of commercial feed for their production while $12 \%$ and $13.56 \%$ of the battery cage and deep litter system user farmers made use of self-prepared feed on their farm.

Comparative Costs and Returns Structure and Profitability Analysis per Bird of Battery Cage and Deep Litter Egg Production Systems by Scale of Operation

Based on the earlier mentioned classification as per the flock size of the poultry farms, a comparative cost, return, gross margin and profitability analysis per bird of an average poultry farmer was done based on the different scales of operation - small, medium and large scale - in the two systems of poultry egg production. As presented in Table 4, the total variable costs for battery cage and deep litter systems on small scale are $\$ 3377.55$ and $\$ 3800.42$; for medium scale, they are $\$ 3739.41$ and $\$ 4024.82$ while that of large scale are $\$ 3610.13$ and \$3169.09 for farms using battery cage and deep litter systems respectively. The TVC accounts for $86.61 \%$, $95.77 \%$ and $95.73 \%$ as well as $90.07 \%, 95.63 \%$ and $93.85 \%$ of total cost of production for small, medium and large scale battery cage and deep litter systems of production respectively. The cost of feed accounts for the highest proportion of the total costs of production closely followed by the cost of the laying bird either at point-oflay or raised from day-old to the point of laying accounts for the next higher proportion of variable cost of production. The total fixed costs per bird are $\$ 522.33$,
$\$ 165.32$ and $\$ 163.58$ for small, medium and large scale battery cage systems and $418.91,183.78$ and 207.76 for deep litter system in the same order.

The revenue per bird from sales of whole eggs for small scale operation in battery cage and deep litter systems is $\$ 5356.90$ and $\$ 5752.58$ respectively; medium scale was estimated as $\$ 452.54$ and $\$ 140.26$; while for large scale they are $\$ 4970.10$ and $\$ 4153.62$ respectively. This accounted for the highest percentage of the total revenue from the business for both systems.

The total revenue for battery cage system are $\$ 5952.04$, $¥ 5187.59$ and $\$ 5376.40$ for small, medium and large scale operations respectively while for deep litter, they are $\$ 6117.17, \$ 5676.06$ and $\$ 4612.90$ also in same order. The gross margin from battery cage and deep litter small scale operation was estimated as 2574.50 and 2316.76 ; medium scale was estimated at 1448.18 and 1651.24 while for large scale, they are $\$ 1766.27$ and $\$ 1443.81$ respectively. The net farm income per bird of battery cage and deep litter small scale operation was put at $\$ 2052.17$ and $\$ 1897.84$ medium scale; 1282.86 and 1467.46 and large scale was estimated at 1605.28 and 1236.06 respectively.

Both the gross margin and net farm income are positive for both systems under the three scales of operation even though they tend to be higher for battery cage systems when compared to that of deep litter systems except for medium scale sized farms. Based on this alone (higher gross margin and net farm income), the choice of battery cage over deep litter system may be encouraged. Also, when we take a look at the rate of return on investment for both systems under the three scales of operation, the RROI is higher in battery cage system when compared with that of deep litter except for under medium scale of production where the rate of return on investment is higher in deep litter system over that of battery cage. The rate of return on fixed cost per bird for battery cage is $429.89 \%$, $876.01 \%$ and $1079.78 \%$ for small, medium and large scale operations respectively while for deep litter, it is $533.04 \%$, $898.49 \%$ and $694.96 \%$ also in same order.

\section{Hypothesis Testing of Difference in Net Farm Income between Battery cage and Deep litter Farms}

The measurement of test of difference in the Net Farm Income between battery cage and deep litter poultry egg farms under the three scales of production was done with the use of t-test of difference of mean with the result presented in Table 5 below. The null hypothesis states that there is no significance difference between the Net Farm Income level of farms using battery cage system and that of farms using deep litter system. The result of the t-test of equal means for Net Farm Income differentials between the Net Farm Incomes per bird of battery cage small scale operation and deep litter small scale operation gave a $t$ statistic of 0.4310 which is not statistically significant. For the difference in Net Farm Income per bird of medium scale poultry egg farms, the $t$ test gave a statistic of 0.7474 which is not also statistically significant.

Also, the $t$ test for difference in the Net Farm Income per bird of battery cage large scale and deep litter large scale farms gave a t statistic of 0.6997 which is not statistically significant. 
Table 4. Costs and Returns Structure per Bird of an Average Poultry Farm Per Annum by Scale of Operation

\begin{tabular}{|c|c|c|c|c|c|c|c|c|c|c|c|c|}
\hline \multirow[b]{3}{*}{ Description } & \multicolumn{6}{|c|}{ Battery Cage } & \multicolumn{6}{|c|}{ Deep Litter } \\
\hline & \multicolumn{2}{|c|}{ Small Scale } & \multicolumn{2}{|c|}{ Medium Scale } & \multicolumn{2}{|c|}{ Large Scale } & \multicolumn{2}{|c|}{ Small Scale } & \multicolumn{2}{|c|}{ Medium Scale } & \multicolumn{2}{|c|}{ Large Scale } \\
\hline & Value & $\%$ & Value & $\%$ & Value & $\%$ & Value & $\%$ & Value & $\%$ & Value & $\%$ \\
\hline \multicolumn{13}{|l|}{ REVENUE } \\
\hline Revenue from Whole Eggs & 5356.90 & 90 & 4752.54 & 91.61 & 4970.10 & 92.44 & 5752.58 & 94.04 & 5140.26 & 90.56 & 4153.62 & 90.04 \\
\hline Revenue from Cracked Eggs & 37.89 & 0.64 & 25.86 & 0.5 & 12.88 & 0.24 & 53.39 & 0.87 & 18.87 & 0.33 & 17.58 & 0.38 \\
\hline Revenue from Culled Layers & 557.26 & 9.36 & 408.07 & 7.87 & 393.42 & 7.32 & 311.10 & 5.09 & 516.85 & 9.11 & 441.71 & 9.58 \\
\hline Revenue From Waste & 0.00 & $\mathbf{0}$ & 1.11 & 0.02 & 0.00 & $\mathbf{0}$ & 0.11 & 0.002 & 0.07 & 0.00 & 0.00 & 0.00 \\
\hline TOTAL REVENUE & 5952.04 & 100 & 5187.59 & 100 & 5376.40 & 100 & 6117.17 & 100 & 5676.06 & 100 & 4612.90 & 100 \\
\hline \multicolumn{13}{|l|}{ VARIABLE COST ITEM } \\
\hline Cost of Birds & 420.02 & 10.77 & 400.82 & 10.27 & 383.91 & 10.18 & 412.07 & 9.77 & 388.91 & 9.24 & 370.00 & 10.96 \\
\hline Cost of Feed & 2161.50 & 55.42 & 2815.92 & 72.12 & 2868.61 & 76.07 & 2655.53 & 62.94 & 3015.98 & 71.66 & 2406.11 & 71.25 \\
\hline Labour Cost & 127.06 & 3.26 & 217.01 & 5.56 & 206.31 & 5.47 & 161.80 & 3.83 & 245.75 & 5.84 & 222.22 & 6.58 \\
\hline Cost of Medication & 262.96 & 6.74 & 127.35 & 3.26 & 50.99 & 1.35 & 189.33 & 4.49 & 112.52 & 2.67 & 49.65 & 1.47 \\
\hline Cost of Energy & 57.68 & 1.48 & 43.11 & 1.10 & 28.38 & 0.75 & 62.16 & 1.47 & 59.64 & 1.42 & 38.55 & 1.14 \\
\hline Cost of Maintenance & 88.87 & 2.28 & 43.22 & 1.11 & 22.79 & 0.60 & 64.16 & 1.52 & 42.74 & 1.02 & 21.76 & 0.64 \\
\hline Administrative Cost & 259.44 & 6.65 & 91.98 & 2.36 & 49.14 & 1.30 & 255.37 & 6.05 & 159.29 & 3.78 & 60.79 & 1.80 \\
\hline TOTAL VARIABLE COST & 3377.55 & 86.61 & 3739.41 & 95.77 & 3610.13 & 95.73 & 3800.42 & 90.07 & 4024.82 & 95.63 & 3169.09 & 93.85 \\
\hline GROSS MARGIN & 2574.50 & & 1448.18 & & 1766.27 & & 2316.76 & & 1651.24 & & 1443.81 & \\
\hline \multicolumn{13}{|l|}{ FIXED COST } \\
\hline Depreciation on Equipment & 4.51 & 0.12 & 8.88 & 0.23 & 11.32 & 0.30 & 19.54 & 0.46 & 19.35 & 0.46 & 40.66 & 1.20 \\
\hline Land Cost & 65.16 & 1.67 & 42.22 & 1.08 & 79.59 & 2.11 & 87.39 & 2.07 & 59.46 & 1.41 & 22.13 & 0.66 \\
\hline Borehole/Deep Well Cost & 3.89 & 0.10 & 13.02 & 0.33 & 8.95 & 0.24 & 32.52 & 0.77 & 9.99 & 0.24 & 10.14 & 0.30 \\
\hline Poultry House/Pen Cost & 32.49 & 0.83 & 20.57 & 0.53 & 17.98 & 0.48 & 279.46 & 6.62 & 94.98 & 2.26 & 134.83 & 3.99 \\
\hline Cage Cost & 416.29 & 10.67 & 80.62 & 2.06 & 45.73 & 1.21 & 0.00 & 0.00 & 0.00 & 0.00 & 0.00 & 0.00 \\
\hline TOTAL FIXED COST & 522.33 & 13.39 & 165.32 & 4.23 & 163.58 & 4.34 & 418.91 & 9.93 & 183.78 & 4.37 & 207.76 & 6.15 \\
\hline TOTAL COST & 3899.87 & 100 & 3904.72 & 100 & 3771.11 & 100 & 4219.33 & 100 & 4208.60 & 100 & 3376.84 & 100 \\
\hline PROFIT & 2052.17 & & 1282.86 & & 1605.28 & & 1897.84 & & 1467.46 & & 1236.06 & \\
\hline RROI & 52.62 & & 32.85 & & 42.57 & & 44.98 & & 34.87 & & 36.6 & \\
\hline RRFC & 492.89 & & 876.01 & & 1079.78 & & 533.04 & & 898.49 & & 694.96 & \\
\hline
\end{tabular}

Source: Field Survey, 2015.

Table 5. Test of Difference of Mean Net Farm Income between Battery cage and Deep litter Poultry Egg Farms

\begin{tabular}{|c|c|c|c|c|c|c|c|}
\hline Variable & Mean Net Farm Income per bird & Standard Deviation & $\mathbf{N}$ & Df & t-value & Sig & Decision \\
\hline Small Scale Battery Cage & 2052.17 & 1691.08 & 35 & \multirow{2}{*}{72} & \multirow{2}{*}{0.4310} & \multirow{2}{*}{0.6678} & \multirow{2}{*}{ Fail to Reject $\mathbf{H}_{0}$} \\
\hline Small Scale Deep Litter & 1897.84 & 1386.52 & 39 & & & & \\
\hline Medium Scale Battery Cage & 1282.86 & 835.8 & 22 & \multirow{2}{*}{35} & \multirow{2}{*}{0.7474} & \multirow{2}{*}{0.4598} & \multirow{2}{*}{ Fail to Reject $\mathbf{H}_{0}$} \\
\hline Medium Scale Deep Litter & 1476.46 & 558.78 & 15 & & & & \\
\hline Large Scale Battery Cage & 1605.28 & 1028.39 & 18 & \multirow{2}{*}{21} & \multirow{2}{*}{0.6997} & \multirow{2}{*}{0.4918} & \multirow{2}{*}{ Fail to Reject $\mathbf{H}_{0}$} \\
\hline Large Scale Deep Litter & 1236.06 & 1107.06 & 5 & & & & \\
\hline
\end{tabular}

Source: Field Survey, 2015.

This result therefore implies that we fail to reject the null hypothesis of equal means meaning that there is no significant difference between the mean Net Farm Income per bird of farms using battery cage system and farms using deep litter system under the different scales of production; therefore it will be safe to say that the mean Net Farm Income per bird of farms using battery cage system is same as the mean Net Farm Income per bird of farms using deep litter system.

Distribution of Technical Efficiencies of Poultry Egg Farmers

The estimates of the efficiency level which serves as a measure of the performance of the each farm against the obtainable performance (frontier performance) is presented in Table 6. The technical efficiency scores of the farms using battery cage and deep litter systems revealed that the mean efficiencies are 0.892 and 0.912 . This result shows that though there is a relatively high level of efficiency among both systems of production, they are yet to attain maximum technical efficiencies, meaning that there is room for improvement for both set of farms in the study area. The mean levels of inefficiencies for the farms are 0.108 and 0.088 for battery cage and deep litter systems respectively. For battery cage system, 27 (36\%) farms are fully efficient while 26 (44.07\%) farms using deep litter systems were fully efficient. 
Table 6. Frequency Distribution of Technical Efficiency Scores of Poultry Egg Farmers Under the three Scales of Operation

\begin{tabular}{ccccc}
\hline & & Battery Cage & \multicolumn{2}{c}{ Deep Litter } \\
\hline Class & Frequency & \%age & Frequency & \%age \\
\hline$<0.60$ & 4 & 5.34 & 0 & 0 \\
$0.60-0.6495$ & 3 & 4 & 0 & 0 \\
$0.65-0.6995$ & 2 & 2.67 & 0 & 6.78 \\
$0.70-0.7495$ & 3 & 4 & 4 & 11.86 \\
$0.75-0.7995$ & 4 & 5.33 & 7 & 8.47 \\
$0.80-0.8495$ & 5 & 6.67 & 5 & 15.25 \\
$0.85-0.8995$ & 7 & 9.33 & 9 & 10.17 \\
$0.90-0.9495$ & 10 & 13.33 & 6 & 47.46 \\
$0.95-1.000$ & 37 & 49.33 & 28 & 0.912 \\
Mean & 0.892 & & 0.716 & 1 \\
Minimum & 0.492 & & 59 & 100 \\
Maximum & 1 & 100 & & \\
Total & 75 & & & \\
\hline
\end{tabular}

Table 7. Tobit Regression Result of Factors Affecting Technical Efficiency of Poultry Egg Farms

\begin{tabular}{lcccc}
\hline & \multicolumn{2}{c}{ Deep Litter } & \multicolumn{2}{c}{ Battery Cage } \\
Variables & Coefficient & T-Value & Coefficient & 5.34 \\
\hline Constant & $1.20011^{* * *}$ & 6.49 & $0.9951^{* * *}$ & -0.42 \\
Age & $-0.0038^{* *}$ & -2.06 & -0.0014 & 1.57 \\
Farm Age & -0.0040 & -0.68 & 0.0064 & 0.08 \\
Years of Experience & 0.0004 & 0.07 & 0.0003 & -2.39 \\
Years of Education & -0.0059 & -0.71 & $-0.0144^{* *}$ & -0.09 \\
Breed of Bird Used & $-0.1159^{* * *}$ & -2.87 & -0.0037 & 3.17 \\
No of Breakages & $0.0026^{* * *}$ & 3.55 & $0.0028^{* * *}$ & -2.61 \\
Membership of Cooperative Society & 0.0198 & 0.51 & $-0.1522^{* *}$ & -1.60 \\
Registration with PAN & $-0.0636^{*}$ & -1.69 & -0.0806 & 0.00 \\
No of Extension Visit & 0.0008 & 0.08 & $0.00001^{* * *}$ & 0.53 \\
Feed Type & $0.1635^{* * *}$ & 4.99 & 0.0385 & 2.82 \\
Gender & $-0.1742^{* * *}$ & -3.55 & $0.1443^{* * *}$ & 0.05 \\
Marital Status & $0.0901^{*}$ & 1.88 & 0.0031 & 1.36 \\
Scale of Production & -0.0098 & -0.22 & 0.0782 & $-3.5992^{* * *}$ \\
Log Likelihood & $-11.0328^{* * *}$ & & 0.1324 & 0.1589 \\
Pseudo R-Square & 0.2955 & & & \\
Mean Square Error & 0.1081 & & & \\
\hline
\end{tabular}

Source: Field Survey, 2015.

The table also reveals that for farms using battery cage system, the minimum efficiency scores are 0.492 and 0.716 for deep litter system with a maximum efficiency score of one for both sets of systems. $62.66 \%$ of the battery cage farms have an efficiency score between 0.90 and one while $57.63 \%$ of farms using deep litter system fall within that category. $87.99 \%$ of the farms using battery cage system have efficiencies between 0.7 and 1 while all the farms using deep litter system fall within that category. This reveals that most of these farms have a relatively high technical efficiency but, there are still some farms that have an efficiency of less than $70 \%$ meaning that they still produce below $70 \%$ of their potential output.

This is in contrast with that of farms using the battery cage system where though there is relative high efficiency, some farms still have efficiency below $50 \%$ which means that the farms using deep litter system are more technically efficient compared to their battery cage counterparts.
This is in contrast with the findings of [20] who found out that farms using battery cage system are more technically efficient compared to those using the deep litter system.

Tobit Estimates of Determinants of the Technical Efficiencies of Poultry Egg Farms

In objective three, the technical efficiency of each farm was evaluated using DEA. Since the production frontier in DEA is deterministic, the resulting efficiencies contain noise from the data [22], therefore, a second stage of analysis is required. In the second stage, some management and socio economic characteristics were used to explain the technical efficiency scores obtained from the DEA model. From the DEA model, the technical efficiency scores range from 0 to 1 , making the dependent variable (efficiency scores) a limited dependent variable.

Therefore, Tobit model is an appropriate model for this second stage of the analysis in order to consider the effect of the farms' management and socio economic 
characteristics on their efficiency scores. In order to know the influence of these management and socio economic characteristics on the different technical efficiencies, Tobit regression was deployed. The Technical efficiency score was regressed on 13 independent variables to identify the factors that determine the technical efficiency of the poultry egg farms.

The coefficient with a positive sign implies that there is a likelihood of an increase in the efficiency of the farms when there is an increase in the independent variable. A negative sign of a coefficient implies that continued use of such variable gives rise to a likelihood of a decrease in the efficiency of such farms.

The significance level of each variable determines the severity of the effect of the variable on the technical efficiency of the farms. The result reveals that for factors that determine the technical efficiency of farms using battery cage system, years of education $(p<0.05)$, number of breakages $(p<0.01)$, membership of cooperative society $(p<0.05)$, number of extension visits $(p<0.05)$ as well as gender $(p<0.01)$ all have significant relationship with the technical efficiency. The negative sign of the years of education implies that the more educated the battery cage farmers are, the less efficient they tend to be. This is contrary to expectations as explained by [23] and [24] that education aids in the adoption and use of improved technological innovations but is in line with the findings of [20] that found a negative relationship between education and efficiency.

The positive sign of the number of breakages implies that the more the no of breakages they have, the more efficient the farms tend to be; this seems rather implausible as it should be expected that more breakages should be a reflection of inefficiency in the system, however, this may be due to the fact that litter farms tend to experience a sizeable number breakages in eggs which would be in various degrees and they may be forced to count the less severe breakages as part of the products.

The membership of cooperative society shows a negative relationship meaning that battery cage poultry egg farms whose proprietors are members of cooperative societies are less efficient than those who are not and this seems to be against the a-priori expectations because members of cooperative societies are expected to be exposed to funds and should be more efficient however, this is in line with the result of [21] who also found a negative relationship between cooperative membership and technical efficiency of poultry egg farmers in Ogun State, Nigeria.

Number of extension visits has a positive relationship with the technical efficiency of the battery cage poultry egg farms which implies that the more extension visits extended to the farms, the more technically efficient they are and this seems to be in line with a-priori expectations as it is expected that the extension agents will avail the farms of latest trends and technologies needed to improve on their production. The positive coefficient of gender suggests that for farms using the battery cage system, male farmers are more technically efficient than their female peers and this may be due to the tendency of more male farmers to have access to funds than female farmers because of their capacity to own assets and ability to provide collaterals and sureties when the need arise as well as the access of males to more amount of family labour which may also be put to use on the farm and the ability of male to control a sizeable number of employees.

Age of the farm manager/proprietor $(p<0.05)$, breed of the birds $(p<0.01)$, number of breakages $(p<0.01)$, registration with PAN $(p<0.10)$, type of feed used $(p<0.01)$ as well as gender $(p<0.01)$ have significant effects on the technical efficiency of poultry egg farms using deep litter system. All except no of breakages and type of feed used have negative relationship with the technical efficiency of the farms. The negative sign of the age of the farm manager/proprietor indicates that older farmers tend to be less efficient compared to their younger counterparts and this may be due to the fact that older farmers tend to be more conservative and less open to the adoption and use of modern technologies than their younger counterparts. This is in line with the findings of $[19,20,21,25]$ who found out that there is a negative relationship between age of farmer and technical efficiencies of their farms.

The coefficient of breed of the birds used shows a negative sign and this implies that farms that make use of the "Isah Brown" breed tend to be less efficient than farms that make use of the other types of layer birds. The positive sign of the number of egg breakages implies that the more the no of breakages they have, the more efficient the farms tend to be; this seems rather implausible as it should be expected that more breakages should be a reflection of inefficiency in the system, however, this may be due to the fact that deep litter farms tend to experience more breakages in eggs than their battery cage counterparts which would be in various degrees and they may be forced to count the less severe breakages as part of the products.

Registration with Poultry Association of Nigeria has a negative coefficient and this implies that farms that are not registered with the Poultry Association of Nigeria tend to be more efficient than the farms that are registered and this also seems to be contrary to expectations because farms that are registered are expected to be availed with timely information on good and qualitative inputs and they are also expected to be in the know of recent development in the poultry industry that should help them take proactive measures in their production. The positive sign of the type of feed used also implies that commercial feed users are more efficient in poultry egg farming than farms that make use of self-formulated feeds.

The negative sign of the coefficient of gender indicates that female farm managers/proprietors are more efficient than their male peers and this is contrary to the findings of $[20,26]$ which found male headed farms to be more technically efficient than their female counterparts.

\section{Conclusions}

The objective of the study is to show which system is more preferable in achieving increased egg production in Nigeria. To achieve this aim, a number of farms using battery cage and deep litter systems were analyzed using appropriate tools. It was found that majority of the poultry farmers were male with a mean age of 44years. The mean number of birds for battery cage was 2868 birds while for deep litter, it was 1289 birds. 
The mean Net Farm Income per bird for farms using battery cage system was not significantly different from the mean Net Farm Income per bird for farms using deep litter system under the three scales of operation indicating that there is no profit loss in engaging in either of the two systems except that if there is land constraint, expansion will be restricted in the case of deep litter system.

The technical efficiency scores of the farms using battery cage and deep litter systems revealed that the mean efficiencies were 0.892 and 0.912 which indicates that though there was a relatively high level of efficiency among both sets of farms, they were yet to attain maximum technical efficiencies, meaning that there is room for improvement (about 10\%) for both set of farms in the study area.

Technical efficiency of farms using battery cage system had a positive relationship with extension visits, number of egg breakages and gender of farm manager/proprietor while it had a negative relationship with years of education and cooperative society membership. The efficiency of farms using the deep litter system possess an incremental relationship with number of egg breakages, type of feed used and marital status but a decreasing relationship with breed of the bird, registration with Poultry Association of Nigeria and gender of the farm manager/proprietor. Male headed battery cage system farms are more technically efficient than their female headed peers while female headed deep litter system farms tend to be more efficient than their male headed counterparts.

\section{Recommendations}

Based on the findings of this study, the following recommendations are advanced with the hope that they will bring about a marked improvement in poultry egg production and help prospective investors into the sub sector of the agricultural economy of the country to make good choices.

1. Little or inadequate capital shouldn't deter prospective farmers from engaging in poultry egg business as they can start with the deep litter system where less capital investments is needed to start the business compared to the battery age system. Also, prospective investors who hope to venture into poultry egg business on the medium scale should look at the deep litter system rather than the battery cage system as it has been found that the medium scale deep litter system farms are more profitable than their battery cage peers in the study area.

2. Women should be encouraged to go into poultry egg farming as they have been found to be more efficient than their male peers in the deep litter system.

3. Poultry Association of Nigeria should facilitate extension services delivery to the poultry farmers in order to improve their managerial capacity.

\section{References}

[1] Bill Leonard (2000). Agriculture in Nigeria. In the Rotary Foundation 2(3): 1
[2] Food and Agriculture Organization. (2003). Agriculture in Nigeria F.A.O of the United Nations, Rome.

[3] Food and Agriculture Organization. (2005). "Livestock Sector Brief: Nigeria. Food and Agricultural Organization of the United Nations FAO: Livestock Information, Sector Analysis and Policy Branch". AGAL Rome, Italy Pg 2.

[4] Yusuf, J.O Anaso, G.N, Vagine, L.I, and Chado, M.O. (1993). Poultry Management Handbook. National Agricultural Extension and Research Liason Services (NAERLS) A.B.U Zaria Extension Bulletin No. 63, Livestock series No. 15. Pages 2-10.

[5] Adetunji, M.O. and Adeyemo, K.E. (2012). Economic Efficiency of Pig Production in Oyo State, Nigeria, A Stochastic Production Frontier Approach. American Journal of Experimental Agriculture, 2(3): 382-394

[6] Ajala, M.K., Adesehinwa, A.O.K. and Mohammed, A.K. (2007). Characteristics of smallholder pig production in southern Kaduna Area of Kaduna State, Nigeria. American-Eurasian Journal of Agriculture and Environmental Sci., 2(2), 182-188, 2007.

[7] Ike P.C (2011). Resource Use and Technical Efficiency of Small Scale Poultry Farmers in Enugu State, Nigeria: A Stochastic Frontier Analysis. International J.ournal of Poultry Science 2011; 10(11): 895-898.

[8] Banga-Mboko, H., Mabas, J.S, and Adzona, P.P (2010). Effect of Housing system (Battery Cage Versus Floor Pen) on Performance of Laying Hens under Tropical Conditions in Congo Brazzaville. Research Journal of Poultry Science, 3(1): 1-4.

[9] Njoya, J and Picard M. (1994). Climatic Adaptation of Laying Hens. Tropical Animal Health Production, 26: 180-186.

[10] Banga-Mboko H., B. Mabanza-Mbandza, P.P. Adzona and C. Batessana (2007). Response a l'alimentation calcique sepearee de lignees commerciales de poules pondeuses shaver sous les conditions tropicales du Congo Brazzaville. African Bulletin of Animal Production and Health, 55:43-50.

[11] Badubi, S.S and Ravindran, V. 2004. A Survey of Small Scale Layer Production Systems in Botswana. International Journal of Poultry Science, 3(5): 322-325.

[12] Rahji, M.A.Y. (2005). Determinants of Efficiency Differentials in Lowland Rice Production Systems in Niger state, Nigeria. Ibadan Journal of Agricultural Research, 1(1): 7-17.

[13] Aladejebi, O. J., Okojie, L.O., and Afolami, C.A. (2014). Comparative production efficiency of battery cage and deep litter systems in the drive towards sustainable poultry egg farming in Ogun State, Nigeria. Journal of Sustainable Development in Africa, Clarion University of Pennsylvania, Clarion, Pennsylvania, 16(4): 139-159.

[14] Ashagidigbi, W.M., Sulaimon, S.A and Adesiyan, A. (2011). Technical efficiency of egg production in Osun State. International Journal of Agricultural Economics and Rural Development, 4 (6):120-131.

[15] Nigeria Bureau of Statistics Federal Ministry of Agriculture and Rural Development (2012). Collaborative Survey on National Agricultural Sample Survey (NASS), Draft Report. Nigeria Bureau of Statistics, Abuja, pp 35-98.

[16] Bamiro, O.M., Shittu, A.M., and Kola-Olutokun A.S. (2001): "Private feed production as a cost reduction strategy: Effects on Profitability of poultry business in Ogun State, Nigeria". The Ogun Journal of Agricultural Sciences., 1(1), pp. 37-51.

[17] Omotosho, O.A. and Oladele, A.A. (1988). Management Problems in Large Scale Poultry Business in Nigeria. Farm Management Nigerian Journal, 3:27-35.

[18] Subhash, S., Joynal, A and Fakhrul, I. (1999). Performance of commercial poultry farms: A Profitability and efficiency analysis, Bangladesh. Journal of Agricultural Economics, 22: 63-75.

[19] Ojo, S.O. (2003). Productivity and Technical Efficiency of Poultry Egg Production in Nigeria. International Journal of Poultry Science, 2:459-464.

[20] Aladejebi, O.J. (2013). Comparative Production Efficiency of Battery Cage and Deep Litter Systems of Poultry Egg Farming In Ogun State, Nigeria. An unpublished M. Agric. Degree Dissertation in the Department of Agricultural Economics and Farm Management, University of Agriculture, Abeokuta.

[21] Afolabi, O. I. (2012). Credit Constraints and Production Efficiency In Poultry (Egg) Farming In Ogun State, Nigeria An unpublished M. Agric. Degree Dissertation in the Department of Agricultural Economics and Farm Management, University of Agriculture, Abeokuta. 
[22] Mohapatra, R and Sen, B. (2013). Technical, Allocative a.nd Economic Efficiency in Sugarcane Production: A Non-Parametric Approach. International Journal of Advanced Research 1(6): 366-374.

[23] Weir, S. (1999). The Effect of Education on Farmers' Productivity in Rural Ethiopia. Centre for the study of African Economies. Department of Economics, University of Oxford.

[24] Oji, U.O and Chukwuma, A.A. (2007). Technical Efficiency of Poultry-Egg Production in Nigeria: Empirical Study of Poultry
Farmers in Imo State, Nigeria. Medwell Research Journal of Poultry Sciences, 1(3-4): 16-21.

[25] Adepoju, A. A. (2008). Technical Efficiency of Egg Production in Osun State. International Journal of Agricultural Economics and Rural Development (IJAERD) 1(1) Pp. 7-12.

[26] Oleke, J. M and Isinika, A. C. (2011). Assessing the technical efficiency of commercial egg production in Tanzania for improved livelihoods. Journal of Development and Agricultural Economics, 3(8), pp. 343-352. 